\title{
Four Scenarios of Malaysia-Indonesia Migration: From the Status Quo to the Wild Card Scenarios
}

\author{
Suyatno, Reevany Bustami \& Ellisha Nasruddin \\ Universitas Kanjuruhan, Malang and Universiti Sains Malaysia, \\ Penang
}

\begin{abstract}
In the context of ASEAN, the number of migrants from Indonesia and Malaysia is the largest. Combining the regular and the irregular migrants, the estimates range from 1.8 million to 3 million people. It is incontrovertible that movement of such magnitude has its impacts, probably both positive and negative. This article aims at providing an analysis based on future scenarios. The purpose is not to make predictions but rather to chart possible paths of critical events that would lead to different scenarios which have different implications to the political, economic and socio-cultural realities. Within this analysis, it is hoped that certain taken-for-granted blind-spots, due to conventional assumptions and mainstream paradigms, will be exposed and examined.
\end{abstract}

Keywords: Migration, Malaysia, Indonesia, Future, Scenarios

Dalam konteks negara-negara ASEAN, jumlah migran dari Indonesia ke Malaysia adalah sangat besar. Apabila dikombinasikan antara migran regular dengan migran iregular perkiraannya antara 1,8 juta hingga 3 juta orang. Ini adalah realita yang tidak terbantahkan bahwa pergerakan sebesar itu tentu memiliki dampak yang sangat besar, baik secara positif maupun secara negatif. Artikel ini bertujuan untuk memberikan analisis berdasarkan skenario masa depan. Tujuannya bukan untuk membuat prediksi melainkan lebih kepada pemetaan jalur peristiwa penting yang akan mengakibatkan skenario yang berbeda-beda, yang pada gilirannya memiliki implikasi yang berbeda dengan realitas politik, ekonomi dan sosial budaya. Dalam analisis ini, diharapkan skenario-skenario tersebut bisa diuji melalui asumsi konvensional dan paradigma mainstream.

Kata-kata Kunci: Migrasi, Malaysia, Indonesia, Masa Depan, Skenario 
Mapping the migration of Malaysia-Indonesia (Malindo) would be very interesting if using Future Studies approach. The Important thing is the events that are now happening could impact on future events whether the events could be a benefit or adverse both countries. To trace the event in the present day toward possibility and impact in the future is a pivotal effort to understand what the matters latter.

Malindo migration has many far-reaching implications for both countries. Therefore, a relation of Malindo is a close relationship. This paper wants to explain that Malindo migration as "Business as Usual" which mutual beneficial to both countries. This paper uses Future Studies approach, such as Probability / Impact Matrix, to try tracing "weak signal" in Malindo migration will become "wild card scenarios". There are many events in current time, such as Bangladeshi workers phenomenon in Malaysia and Chinese workers exodus in Indonesia. This approach could analyse this event and to find out the opportunities and challenges in the future, may occur with a high impact. To completing analyze this paper want to explain first about this concept in below, such as "weak signal", "wild card", "wild card scenarios", and also Impact/Probability Matrix.

\section{Future Studies: Weak Signal, Wild Card, Wild Card Scenarios and Impact/Probability Matrix}

It is very interesting to understand Malaysia-Indonesia (MALINDO) relations that using future studies as a tool to study probability and impact of their relations in the future. There are many events today can influence the future not only in terms of benefit but also a disadvantage for both of them or one of them. Futures studies (FS) is not just about some techniques used to investigate the futures, as Mariene (2002) also insists FS is not really a separate field. Many works done in this field is multidimensional. In fact, future is a resultant vector created by many factors. Some of these factors change this vector more and some of them actually don't matter to be happened.

As a first step to explore "wild card" is discussed "weak signal" which can, however, be viewed in another way: as a means of anticipating future "wild cards" (Mendonça et al. 2004; Petersen 1999). To separate a "wild card" from a "weak signal" it is helpful to point out the essential aspect of these two concepts. "weak signal's" are currently existing small and seemingly insignificant issues that can tell us about the changes in the future. In other words, they are today's clues and signs providing us with hints of the possible events and trends in the future. For the future purposes, "weak signal's" are, above all, a tool for avoiding blindness in foreseeing gradual changes and reacting to them in time. Collecting and 
analyzing "weak signal's" could be a key to anticipating changes in advance and avoid letting them cause surprise. By contrast, "wild cards" are surprising events with huge consequences. They have either happened in the past or are ongoing right now. In regard to a futures perspective, it would make more sense to talk about "wild card scenarios", which are scenarios dominated by an imaginary, sudden event with dramatic consequences (Hiltunen 2006). In other words, they are today's clues and signs that provide us with hints of possible events and trends in the future. With hindsight, "weak signal's" providing hints about future events can also be indicated from the past. By contrast, "wild cards" are surprising events with huge consequences. They have either happened in the past or are happening at the moment. Further, below will be explained in detail about the "wild card".

Mendonça et al. (2004) emphasize that "wild cards" can be anticipated by watching "weak signals" of them. They use Coffman's (1997a) definition of "weak signal's", according to which a "weak signal" is: (1) an idea or trend that will affect how we do business, what business we do, and the environment in which we will work; (2) new and surprising from the signal receiver's vantage point (although others may already perceive it); (3) sometimes difficult to track down amid other noise and signals; (4) a threat or opportunity to your organization; (5) often scoffed at by people who "know"; (6) usually has a substantial lag time before it will mature and become mainstream; and (7) therefore represents an opportunity to learn, grow and evolve. Mendonça et al.(2004) emphasize that by scanning "weak signal's" in the environment, some wild cards can be anticipated. For those wild cards that cannot be anticipated, organizational improvisation is needed for dealing with ongoing crises.

Peterson (1999) believed wildcards happen quickly and the social system won't be able to respond them effectively. Petersons brings up three principles to clarify the concept of Wild cards, first of all, he mentions the importance of thinking of "wild cards" before the occurrence, so that if we think after it is completely meaningless. The second principle is about the information and how we can find it. Experts' opinions should be taken seriously so that it refers to Delphi method. And the third one exactly distinguishes approaches to "wild cards", as extraordinary approaches are introduced to track extraordinary events. Petersen (1999, 4) suggests that "wild cards" are "low-probability, hi-impact events that happen quickly" and "they have huge sweeping consequences." "Wildcards", according to Petersen, generally surprise everyone, because they materialize so quickly that the underlying social systems cannot effectively respond to them.

At meanwhile Mendonça et al. $(2004,201)$ define a "wild card" as "sudden and unique incidents that can constitute turning points in the 
evolution of a certain trend." They continue that a "wild card" is assumed to be improbable, but it would have large and immediate consequences for organizational stakeholders if it were to take place. They also see "wild cards" as "one of the most unpredictable and potentially damaging triggers of change of four conceivable components of change: trends, cycles, emerging issues, and wild cards" (Mendonça et al., 2004, 203). To draw conclusions from this discussion, one can notice, that "wild cards" are typically considered to be surprising (low-probability) and hiimpact events (Hiltunen 2006).

More specifically, Hiltunen (2006) distinguished between "wild card" and "wild card scenarios". In regard to the future perspective, it would seem to make more sense to talk about "wild card scenarios" rather than plain "wild cards", as they are scenarios that are dominated by imaginary, sudden events that have dramatic consequences. Hiltunen (2006, 65) also explained that "weak signal's" exist here today. With hindsight, it is also possible to point out "weak signal's" in the past that were hinting about future events and trends. "Wild cards" are sudden surprising events that have happened or might happen in the present. "Wild card" scenarios are our images of a future state in which an imaginary surprising event has a dominating effect. The low probability characteristic of a wild card may have come into existence because scenarios have typically been divided into possible scenarios (everything that can be imaged), realizable scenarios (all that is possible, taking account of constraints) and desirable scenarios (which fall into the possible category, but which are not all necessarily realizable) (Godet 1993, 56). To investigate wild cards in this framework, low probability is a legitimate characteristic of a "wild card".

Furthermore, this paper will be given an explanation of the Impact/Probability Matrix to complement explanation of the concepts above. This matrix is essential to map out where the actual position of the "wild card" distinguishing degrees of impact and the degree of probability. Garland $(2007,116-118)$ gives a complete explanation of this matrix. The matrix presents four potential scenarios and compares each scenario's potential impact and probability. To use the matrix correctly, it is important to understand these terms: (1) Impact is the estimation of whether a trend could be mildly disruptive, requiring a few new practices, or disturbing, perhaps even requiring a change of business altogether; (2) Probability is a measurement of how likely a scenario is and what events would bring it about. The Impact/Probability Matrix produces several scenarios with distinctly different characteristics. The figure below illustrates one way to structure scenarios in the matrix. 


\section{Figure of Impact/Probability Matrix}

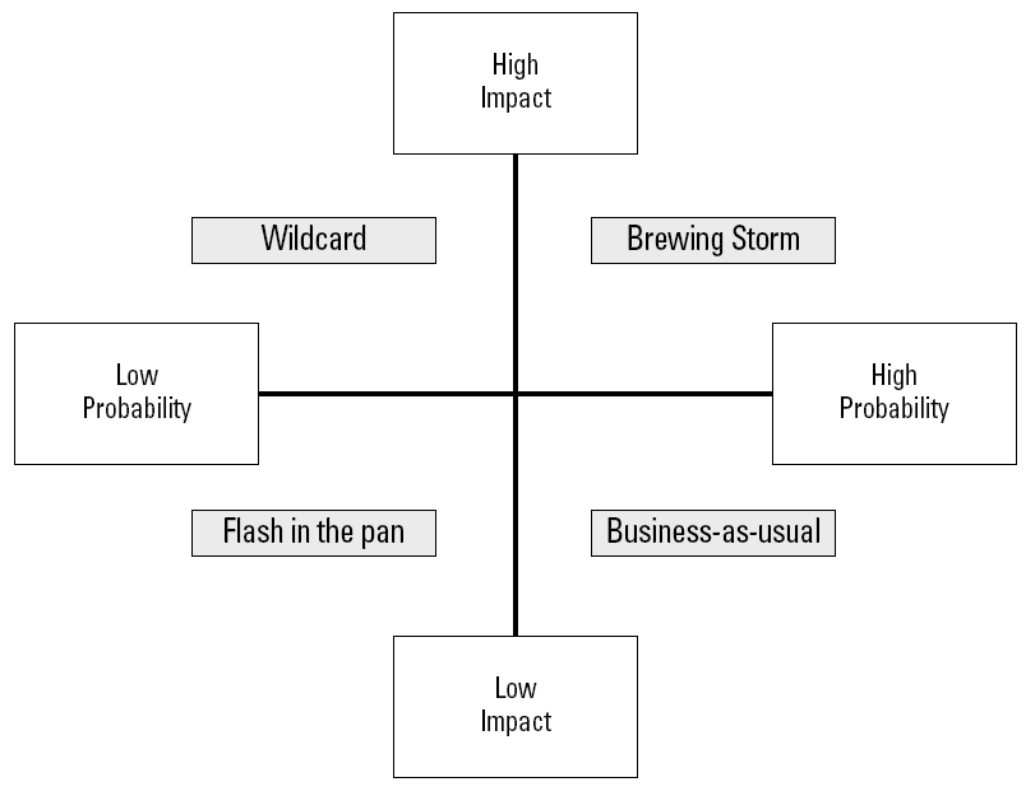

Source : Eric Garland (2007). Future Inc.: How Businesses Can Anticipate and Profit from What's Next. AMACOM, New York.

Low Probability, Low Impact-Flash In The Pan: This scenario shows a future that could turn out to have little disruption and, thus, any overreaction would be wasted energy. This scenario is often premised on the idea that the coming change will not be a big deal or that it will blow over quickly.

High Probability, Low Impact-Business As Usual: A change is coming, but we can adjust to it without any major growing pains. We need to observe the forces at play see if some things will change, but our business will remain fundamentally unchanged.

High Probability, High Impact-The Brewing Storm: This is often what executives focus on most, a scenario signaling a real problem. You can see the path of this brewing storm, and an exploration of this future will point to signs we need to watch for.

Low Probability, High Impact-Wild Card: Wild cards are those scenarios that are unlikely but could arrive if a couple of events come in rapid succession and change everything. It is the blindside, the "We never saw it coming." The stars would really need to line up, but if they did, lack of preparation would result in severe consequences. 
For the purpose of this paper, it will focus on "Business as Usual" and "Wild Card" as the main discussion analysing Malaysia - Indonesia (Malindo) Migration. This migration is a normal phenomenon as modern consequences of a lifetime that has an economic reason for migrant leaving Indonesia toward Malaysia as a country destination. According to Impact/Probability Matrix, this phenomenon can be put in Business as Usual. This paper would like to draw impact of migration possibility in the future through to trace from "Business as Usual" to "Wild Card". The writer prefers "Wild Card" rather than Brewing Storm and Flash in the Pain since "Wild Card" is an important phenomenon, that called "future quakes", which has high impact in the future. Steinmuller (2003) takes Chernobyl disaster as an example. The Chernobyl disaster was not only one more reactor accident (of a yet unknown dimension). It happened without any precedent since it changed the way most people are thinking about the "peaceful use of the atom". If the future is the space of our hopes and fears, our wishes and plans, or, more generally our expectations, "wild cards" are shocks to this space. They are "future quakes" changing all of the landscape of the future.

There are a lot of more examples in the history of wild cards, such as 11th September event, 2008 financial crisis, and some natural disasters like Tsunamis. Because these events have happened before one time, then we give them a more chance of occurrence. This phenomenon is important as people believe is one critical parameter making the future. If a lot of people believe in something to happen, then the chance of occurrence increases because minds are ready to accept it.

\section{'Business as Usual' for Economic and Demographic Drivers of Malindo Migration}

According to International Organization for Migration (IOM), the flow of Indonesian domestic workers into Malaysia can be seen as a structural phenomenon driven by economic and demographic disparities within the region. Malaysia is the top destination areas in South-East Asia for Indonesian migrants, the majority of whom are women employed as domestic workers, nannies, and elderly care workers (IOM 2010). Qualitative studies have shown that the main driving factors behind this type of migration are often economic (Ford 2001; Human Rights Watch 2005; Anggraeni 2006; IOM 2010). Pay differentials provide a strong incentive for these women to migrate abroad in order to improve their livelihoods and social status. As illustrated in Table 1, High levels of unemployment and underemployment in Indonesia make it difficult for individuals (and particularly women) seek job opportunities locally. 
Table 1.

Economic Indicators for Indonesia and Malaysia

\begin{tabular}{|c|c|c|c|}
\hline Indicator & Year & Indonesia & Malaysia \\
\hline Population (millions) & 2010 & 232.5 & 27.9 \\
\hline GDP per capita (USD) & 2008 & 2,246 & 8,209 \\
\hline $\begin{array}{l}\text { Unemployment rate (\% of labour } \\
\text { force) }\end{array}$ & 2009 & $7 \cdot 7$ & 5.0 \\
\hline $\begin{array}{l}\text { Female population with at least } \\
\text { secondary education (\% ages } 25 \& \\
\text { older) }\end{array}$ & 2010 & 24.2 & 46.7 \\
\hline Human Poverty Index (HPI) rank & 2007 & 69 & 25 \\
\hline \multicolumn{4}{|c|}{$\begin{array}{l}\text { Source: Adapted and compiled from ILO (2010); UNDP Human } \\
\text { Development } \quad \text { Report } \\
\text { http://hdr.undp.org/en/media/HDR_2010, } \\
\text { the United Nations Statistics Division, available at http://data.un.org }\end{array}$} \\
\hline
\end{tabular}

Malaysia has experienced significant labour shortages in the low-wage sector since the late 1970s, owing to its state-led industrialization program - namely, the New Economic Policy (NEP) between 1971 and 1990, and the National Development Policy (NDP) between 1991 and 2000 - which sought to diversify the nation's economy through export promotion and the establishment of an educated workforce (Chin 2002; Kaur 2010). In these destination areas, rapid industrialization and an increase in women's participation in the workforce resulted in a steady rise in the number of dual-income families, which was accompanied by a strong demand for migrant domestic workers who served as paid substitutes for the social reproductive labour needed within these middle-class households (Huang and Yeoh 1996).

Economic reasons drive the majority of Indonesian labour migrants to migrate abroad, to improve the economic status of themselves and their families. High levels of unemployment and underemployment in Indonesia push many individuals to look for jobs in abroad. Many of them decide to go abroad after hearing about the availability of jobs from recruitment agents and social networks and the higher salaries on offer abroad in countries such as Malaysia, Saudi Arabia, Hong Kong SAR, Kuwait, Singapore and the United Arab Emirates. Many individuals, especially women, see migration abroad as the only way out of poverty for them and their families. Most workers, therefore, migrate intending to work abroad for only a limited time to save enough money to purchase a house, open a business or send their children or relatives to school. Although labour migration from Indonesia is characterized as temporary because few migrants leave intending to settle in the destination country, they rarely stay even if they change their mind. Due to the high costs 
often associated with securing overseas employment, temporary labour migration often turns into a stay that is longer than expected and may last several years.

This phenomenon can be put in "Business as Usual" because they have a low impact but a high probability. Malindo migration has a low impact on for Malaysia this phenomenon is a just usual economic development that needs migrant workers supply. In another side, for Indonesia, this is a good opportunity for a citizen who need a job. Since Malaysia economically advanced rather than Indonesia and geographically is closer distance so it rise many possibilities for both of countries to do push and pull factors migration. This is the reason, why the number of Indonesia migrant to Malaysia is one of the largest migrations in the world. Perhaps the world's second-largest, long-term undocumented migration flow, overshadowed only by the traffic between Mexico and the United States, is that between Indonesia and Malaysia. It is a movement whose history goes back to pre-colonial times and one that has reached very substantial levels in the last two decades (Hugo, 2007).

\section{Wild Card Scenarios: Bangladeshi and Chinese Workers}

Discussion about "wild card scenarios" in Malaysia can be started by mapping the rise of the phenomenon of foreign worker policy in Malaysia. The Malaysian government has planned to bring in Bangladeshi workers as many as 1.5 million people during the following 3 years. This is a serious fact/problem that jobs competition between Indonesian and Bangladeshi workers will become a potential conflict in the future.

Another phenomenon is the influx of Chinese workers throughout the world. The BBC reported that tens of thousands of Chinese workers were coming to Angola, Africa, to work in urban development project after the civil war occurred in the country for a few years. Luanda as the capital city in Angola is developing regularly then makes China investors are coming at Angola. But there is a consequence/commitment which workers must also be brought from China. This is the reason that some China workers in Angola are working in construction and infrastructure sectors.

The influx of Chinese workers also becomes a common phenomenon in Indonesia. This is a "weak signal" that could lead the emergence of a "wild card". Therefore, the following explanation will discuss the "weak signal" of Bangladeshi and Chinese workers who are emerging and tend to be "wild card scenarios". 


\section{Bangladeshi Workers and Future Conflict: Scenario \#1}

In Malaysia, migrant workers come from more than 12 countries in Asia with the majority coming from Indonesia, according to Fair Labour Association, an international non-profit collaboration promoting international labour laws. Bangladesh, Nepal, India, Pakistan, Vietnam, Cambodia, Thailand and the Philippines supply a large number of the migrant workers' population in Malaysia. There are about 2.9 million legal foreign workers in Malaysia (out of an estimated 6 million, but the issue of illegal migrant workers is a separate story), citing figures provided to them by the police. National labour statistics show that nearly $40 \%$ of migrant workers had no formal education, as compared to the $10 \%$ with tertiary experience. It is also worth noting that the share of migrants working in white-collar occupations has plummeted dramatically from a peak level of $10 \%$ in 2002 to $5.8 \%$ in 2008 due to rising domestic education and expertise levels (Malaysiandigest 2015).

Because The Malaysian government plans to bring Migrant Workers of Bangladesh (Bangladeshi workers ), it can change the phenomenon. The objective of the policy is to cut the number of illegal migrants or irregular migrants, besides filling labor needs in the plantation, construction, manufacturing and service sectors. Home Minister Datuk Seri Ahmad Zahid Hamidi said his ministry had intensified efforts to deport all illegal foreign workers to their countries of origin before bringing approximately 1.5 million workers from Bangladesh to Malaysia. He said the ministry, through the Immigration Department, police, RELA and other agencies, had also intensified their cooperation to carry out joint enforcement to flush out illegal foreign workers in the peninsula, as well as in Sabah and Sarawak. The minister said the Prime Minister Datuk Seri Najib Tun Razak's effort to bring in the Bangladeshi workers was aimed at meeting the demands of employers in the plantation, construction, manufacturing and service sectors (Awani 2015).

The government of Malaysia efforts to bring in workers from Bangladesh in a very large number. It will reduce the significant opportunity of Indonesian workers. Similar work sector will become a hard competition between Indonesian and Bangladeshi workers. Thus, could be regarded as a "weak signal" in the form of "wild card scenarios". There is also emerging high impact of rivalry between Indonesia and Malaysia workers in the future. But its probability quite small due to implementing these policies have been consistent and good collaboration.

As explained above, related to Indonesian point of view, Malindo migration is more supported by economic and demographic as a "push factor". Besides, Malaysia as a "pull factor" country that became a 
destination for Indonesian workers will carry out a new policy bring in the Bangladeshi workers. It will appear various possibilities and has high impact in the future. Furthermore, the emerge of a "wild card" can't be avoided. There are many forms of conflict, such as the conflict between workers since they worked at similar areas of working. In state level, that matter could trigger conflict between Indonesia and Malaysia because Indonesia workers are more difficult to get a job in Malaysia. In turn, it will encourage diplomatic issue between two countries.

\section{Chinese Workers and Future Conflict: Scenario \#2}

The bureau published the 2012 Investigational and Monitoring Report of Chinese Migrant Workers, according to Xinhua News, China's stateowned news agency. At the end of 2012, the number of migrant workers in China increased by 3.9 percent to 262.61 million. Migrant workers were previously farmers or were farmers ancestrally, and as China has modernized have chosen to seek more profitable, most often industrial work, in urban centers across the country. Many - 160 million in $2012-$ choose to migrate to metropolitan cities farther away from their home regions (International Business Times 2013).

The data above shows how the potential of Chinese migrant workers is enormous. In cooperation policy, the China government enclose an important clause i.e. bringing their workers in particular in construction and infrastructure development. It is occurred in Indonesia recently. When the issue of employment is still a serious problem in Indonesia, the arrival of Chinese workers becomes a new problematic phenomenon even though strengthening cooperation between Indonesia and China.

There was a major issue that thousands of Chinese workers have been overflow in Serang, Banten. The Indonesian government has denied this fact as stated by the Minister of Manpower (Menaker), Hanif Dakhiri in various media and social media on their invasion of foreign workers from China to Indonesia. "Related to the issue about invade Chinese workers was not true. We must make sure that any foreign workers in Indonesia must follow the procedure of getting work permits and did not violate the rules of employment," Dakhiri said in a press release by Public Relations section of the Ministry of Manpower (Kemenaker) in Cilacap, Central Java (Setkab 2015).

Ministry of Manpower data shows the number of foreign workers in Indonesia is dominated by Chinese workers in 2013. Overall, the number of foreign workers working in Indonesia has declined in the past year. Based on data Permits Employing Foreign Workers (IMTA) issued by the Ministry of Manpower and Transmigration for the year 2013 there 
was 68,957 foreign workers in Indonesia. The number of foreign workers in 2013 decreased when compared with the number of foreign workers in Indonesia in 2012 that number reached 72,427 people and in 2011 as many as 77,307 people. However, in earlier years the foreign workers who come from China, Japan, and South Korea, India and Malaysia still dominated the total number of foreign workers in Indonesia. The presence of foreign workers from five Asian countries dominated foreign workers from year to year. In 2013, foreign workers from China amounted to 14,371 , followed by Japan $(11,081)$, South Korea $(9,075)$, India $(6,047)$ and Malaysia $(4,962)$.

The data above shows a significant number of foreign workers from China that increase every year. Cooperation between Indonesia and China government also developed which can be seen from the number of Chinese investment projects in Indonesia. It is a "weak signal" that leads to the "wild card scenarios". While the employment problem in Indonesia is still a serious problem, the arrival of foreign workers will be a "time bomb" in the future. The battle over jobs could be inevitable. Indeed, its probability is small because government policies are implemented gradually. Yet so, if the exodus of Chinese workers cannot be avoided, then it will happen, that is horizontal high impact conflicts. It will be a major issue among local workers and Chinese workers. If the conflict is not inevitable, the scale of the conflict will increase to problems between Indonesia and China at the state level. "Wild card" as conflicts in the future will be a big problem for Indonesia. The implication may spread to the neighbour country, such as Malaysia.

\section{Wild Card of Malindo Migration}

Based on the above explanation, Scenario \# 1, argue that the policy of Malaysia to bring 1.5 million Bangladeshi workers is "weak signal", hereafter will bring new "wild card scenario". Seizing the labour sector between the Bangladeshi and Indonesian workers will become the "wild card" that emerge a problem of conflict not only between labour but also between two countries. For the current time, Malindo migration still reflects to "Business as Usual" scenario since Indonesian workers work normally in Malaysia. It will shift to "wild card" scenario when the government of Malaysia carries out a new foreign workers' policy which brings Bangladeshi workers at the large number in a period of 3 years. The appearance of "wild card" in this case is an inevitable future conflict, either Indonesian workers or Bangladeshi workers, but also can appear a conflict between Malaysia and Indonesia. 
Scenario \# 2 is called a "wild card" or Malindo "future quake". Chinese workers in large numbers are something that could happen because the potential of China labor is more than Malindo population itself. When the local workforce is getting squeezed by Chinese workers and the opportunity of Malaysia as a work destination country also limited, due to millions of Bangladeshi workers, hereafter will appear "wild card scenario". Another form of "wild card scenarios" is the Indonesian government policies which encourage the Chinese government to be more robust in a series of cooperation in investment. If the agreement is done and at the same time the Indonesia government indifferent to the negative impact of the job availability, then it will become "wild cards" in the future. The appearance is a conflict between labor and conflict in state level. The probability of conflict is quite small because the government, however, work with policy with considerable caution and respect. But once the conflict applies the "future quakes" will certainly not inevitable.

Scenario \# 2 also has strong relevance to Malaysia position. If many Indonesian workers are frustrated to get a good job in their own country and in Malaysia, that is the potential instability of social, economic and political problem. It would be a serious problem between Malaysia and Indonesia. Ship piracy incident in Malaysia, Orkim Harmony for example, by the citizens of Indonesia, has recently become "weak signal" that Indonesian workers frustrated to get a job are likely to challenge region security. The overflow of Bangladeshi workers in Malaysia and the Chinese workers in Indonesia will increase region security problem in particular in Malindo . It means "Business as Usual" scenario can turn into a "wild card" or a real conflict in the future. The argument can be stated that both of scenarios could happen anytime and turned into a high-impact wild card.

\section{Conclusion}

Observing the events can be categorized as an effort to identify "weak signal" that has a low probability can turn into a dangerous "wild card". Future Studies help analyze the future through a mapping of events in the present so that future problems can be avoided wisely. The policy of foreign workers by Malaysia and Indonesia governments should pay attention to "weak signal". If the government is only oriented to increase economic growth through investment cooperation but ignored the phenomenon of migration, it is likely to appear dangerous "wild card" scenario. 
With the new policy of foreign workers, Malaysia government plan to bring millions of Bangladeshi workers. It should take into account the chances of conflict (wild card scenario) because nowadays the majority of foreign workers in Malaysia are from Indonesia. This competition could spark conflicts anytime. The worst scenario would emerge is the conflict not only at labour level but also at the state level in the name of the sovereignty and dignity of their respective countries.

In Indonesia, the government has committed to increasing investment cooperation with China. The consequences are to open opportunity for Chinese workers to compete looking for a job with local workers. It can rise a new conflict (wild card scenario), due to unresolved the employment problem in Indonesia. Scramble jobs can raise fuel conflict. On the one side, a sense of frustration in Indonesia could be a major cause of conflict, when the competition gets so tight employment with Chinese workers. On the other side, the migration opportunity to Malaysia for employment also very competitive because the Malaysian government implements a new policy. Wild card scenario will encourage political instability which the real horizontal and vertical conflicts become unavoidable. This phenomenon can grow "wild card scenario", which in turn to "wild card" in the future. It will enhance the challenge of national and regional security. This is an important warning for Malindo for the sake of a good future together.

\section{References}

\section{Books}

Anggraeni, D. (2006). Dreamseekers: Indonesian Women as Domestic Workers in Asia. Equinox Publishing and ILO. Jakarta.

Garland, Eric. (2007). Future Inc.: How Businesses Can Anticipate and Profit From What's Next. AMACOM. New York.

Godet, Michael. 1993. From Anticipation to Action-A Handbook for Strategic Prospective. France: UNESCO.

Petersen J.L (1999). Out of the Blue: How to Anticipate Big Future Surprises? Madison, Lanham.

\section{Journals}

Chin, C.B.N. (2002). “The 'Host' State And 'Guest' Worker In Malaysia: Public Management And Migrant Labour In Times Of Economic Prosperity And Crisis'. Asia Pacific Business Review, 8(4): 19-40. 
Ford, M. (2001). "Indonesian Women as Export Commodity: Notes from Tanjung Pinang," Labour Management in Development Journal, 2(5): 2-9.

Hiltunen, Elina. (2006). "Was It a Wild Card or Just Our Blindness to Gradual Change?” Journal of Futures Studies, November 2006, 11(2): 61 - 74 .

Huang, S., and Yeoh, B.S.A. (1996). "Ties that bind: state policy and migrant female domestic helpers in Singapore", Geoforum, 27(4): 479-493.

International Organization for Migration (IOM). (2010). Labour Migration from Indonesia: An Overview of Indonesian Migration to Selected Destinations in Asia and the Middle East. IOM. Jakarta.

Kaur, A. (2010). "Labour Migration Trends and Policy Challenges in Southeast Asia". Policy and Society, 29 (4): 385-397.

Mariene, M. (2002). "Futures Studies in the 21st Century: a Realitybased View", Futures, Vol. 34 Nos 3/4, pp. 261-81.

Mendonca, S., Cunha, M., \& Kaivo-oja, J., \& Ruff, F.(2004). "Wild Cards, Weak Signals and Organizational Improvisation”, Futures, Vol 36, PP 201-218.

\section{Internet}

"Illegal workers to be deported before the arrival of Bangladeshi workers". June 27, 2015. http://english.astroawani.com/malaysianews/illegal-workers-be-deported-arrival-bangladeshi-workers63966?cp. [accessed 25 June 2015].

"Inilah Penjelasan Menaker Hanif Dakhiri Soal Isu Eksodus Tenaga Kerja Asing Asal China Ke Indonesia”. 30 Jun 2015. http://setkab.go.id/inilah-penjelasan-menaker-hanif-dakhiri-soalisu-eksodus-tenaga-kerja-asing-asal-china-ke-indonesia/. [accessed 25 June 2015].

"Migrant Workers: Malaysia's 'Invisible' Workforce", 10 February 2015. http://www.malaysiandigest.com/features/541277-migrantworkers-malaysia-s-invisible-workforce.html. [accessed 25 June 2015].

"China Now Has More Than 260 Million Migrant Workers Whose Average Monthly Salary Is 2,290 Yuan (\$374.09)”. May 282013. http://www.ibtimes.com/china-now-has-more-26o-millionmigrant-workers-whose-average-monthly-salary-2290-yuan37409-1281559. [accessed 25 June 2015].

Hugo, Graeme. (2007) "Indonesia's Labor Looks Abroad." Available at http://www.migrationinformation.org/Profiles/display.cfm?ID=5 94, accessed on 13 September 2007. [accessed 25 June 2015]. 
Human Rights Watch. (2005). "Maid to Order: Ending Abuse against Migrant Domestic Workers in Singapore". In http://www.hrw.org/sites/default/files/reports/singapore1205wc over.pdf. [accessed January 21, 2015].

The United Nations Statistics Division, available at http://data.un.org. [accessed 25 June 2015].

UNDP Human Development Report 2010, available at http://hdr.undp.org/en/media/HDR_201O_EN_Complete.pdf. [accessed 25 June 2015]. 